\title{
O CORONAVÍRUS NOS CONVID(A) A \\ REPENSAR NOVAS LINHAS DE CUIDADO
}

Diego Floriano de Souza

loná Vieira Bez Birolo

\section{DOI: http://dx.doi.org/10.18616/intcov05}

Com o advento na China, da pandemia da covid-19, que vem se disseminando rapidamente por todos os continentes, rompem alguns desafios, devido à facilidade de contágio do vírus e seu potencial de propagação em espaços fechados. Por conta desses fatores, o isolamento social se faz necessário, evitando, dessa forma, a busca massiva dos serviços de saúde por usuários. No entanto, surgiram alguns nós críticos: como garantir a continuidade do cuidado com a saúde em tempos de pandemia? Este relato tem por objetivo descrever a experiência do cuidado em saúde, por meio de uma ferramenta de teleatendimento durante a pandemia da covid-19.

Frente a esse paradoxo, imposto pela nova pandemia, abre-se a oportunidade de criar linhas de cuidado, novos modos de cuidar da vida e de saúde da população (MERHY; FRANCO, 2003).

A Universidade do Extremo Sul Catarinense (UNESC) disponibi- 
tros níveis de atenção e, por fim, auxiliar no itinerário dos usuários dentro do sistema. Considerando o grande número de afastamentos laborais de muitos profissionais de saúde na vigência da epidemia, o teleatendimento possibilita a esses profissionais atuarem remotamente.

Porém existem algumas dificuldades, que vão desde a operacionalização das ferramentas pelos usuários até o modo como os profissionais se veem e atuam nessa nova modalidade de atendimento. Acredita-se que essa última dificuldade seja a mais delicada de ser compreendida e superada, pois, à medida que o teleatendimento possibilita novas linhas de cuidado, requer novos modos de produção desse cuidado, exige maior capacidade inventiva para o relacionamento entre profissional e paciente. Sendo que, a dificuldade em atuar na prevenção inicia ainda na formação, que possibilita poucos momentos de experimentação de ações como essas, de trabalho vivo e ato (MERHY; FRANCO, 2003).

O teleatendimento tem se mostrado uma alternativa eficiente no combate à pandemia da covid-19, no entanto, exige um movimento de Educação Permanente em Saúde dos profissionais, a fim de reconhecer as lacunas de sua atuação. Desse modo, espera-se superar as limitações do profissional, pois quando voltado para a lógica biomédica, muitas vezes, condiciona sua atividade, reduzindo a dimensão cuidadora à lógica curativista.

\section{REFERÊNCIAS}

MERHY, Emerson Elias; FRANCO, Túlio Batista. Por uma composição técnica do trabalho centrada nas tecnologias leves e no campo relacional. Saúde em Debate, Rio de Janeiro, v. 27, ano 2002, n. 65, set./dez. 2003.

\section{OBRAS CONSULTADAS}

WORLD HEALTH ORGANIZATION (WHO). Coronavirus. 2020. Disponível em: https://www.who.int/westernpacific/health-topics/coronavirus. Acesso em: 20 jun. 2020; 